\title{
Listening to Australian Indigenous men: stories of incarceration and hope
}

\author{
John Macdonald ${ }^{1}$, Tony Scholes ${ }^{2}$ and Kay Powell ${ }^{3}$ \\ ${ }^{1}$ Foundation Chair in Primary Health Care, Director MHIRC, School of Science and Health, Western Sydney University, \\ Penrith, NSW, Australia \\ ${ }^{2}$ The Men's Health Information and Resource Centre (MHIRC), Western Sydney University, Hawkesbury Campus, \\ Richmond, NSW, Australia \\ ${ }^{3}$ Research Assistant, The Men's Health Information and Resource Centre (MHIRC), Western Sydney University, \\ Hawkesbury Campus, Richmond, NSW, Australia
}

\begin{abstract}
Objective: This paper reports on a project conducted between 2008 and 2011 that was established to allow eight Australian Indigenous men who had been in prison to tell their stories of incarceration. Background: The Shed in Western Sydney, NSW, Australia, was set up in response to the high male suicide rate in that area, its objective being to support men at risk. Aboriginal men were the most at risk, and they are presently imprisoned at a rate of 13 times more than non-Indigenous men. This small project sought to give voice to the men behind the statistics and point to a significant problem in Australian society. Methods: Interviews were conducted by an Indigenous male, questions covering age at first entering the penal system, number of prison stays, support, and health. This paper is framed around responses to these questions. Results: All but one of the men were recidivist offenders, and over half were under 15 years of age when first offending. All talked about a lack of support both inside and after leaving prison, and alcohol and depression figured strongly in the accounts. Disadvantage and social exclusion, lack of support such as access to housing and health services, figure significantly in the men's stories. It is only when social issues are addressed that any gains will be achieved and a cycle of recidivism broken.
\end{abstract}

Key words: imprisonment; Indigenous issues; men's health; recidivism; social determinants of health

Received 20 February 2016; revised 27 June 2016; accepted 4 July 2016; first published online 12 August 2016

\section{Jumna Wal}

'Jumna Wal', in the traditional language of the Darug people of Mt Druitt, Western Sydney, means 'We Care'. Between 2008 and 2011, a cottage on the Hawkesbury campus of Western Sydney University, Australia, became the venue of a project called Jumna Wal, one of the purposes of which was to collect the stories of Indigenous men who have spent time in prison, and who were

Correspondence to: Kay Powell, The Men's Health Information and Resource Centre (MHIRC), Western Sydney University, Hawkesbury Campus, Building P11, Londonderry Road, Richmond, NSW 2753, Australia. Email: j.macdonald@ westernsydney.edu.au attempting to reintegrate into society. This article looks at the impact of incarceration on eight men. In the spirit of people's participation in primary health care this work gives voice to some of the men themselves.

\section{Background}

In 1991, the Royal Commission into Aboriginal Deaths in Custody (RCADC) found that the reason for the high rate of deaths of Indigenous men in custody was that Aboriginal men were more likely to be in custody, the figure being as much as five times that of non-Aboriginal men (Cunneen, 2006). At the time of the Commission, whilst accounting for $2.3 \%$ of the general population,

(C) Cambridge University Press 2016 
Aboriginal men constituted $14 \%$ of the prison population. Since then, despite the recommendations of the Royal Commission, this figure has increased and now an Aboriginal male is 13 times more likely to be taken into custody than a nonAboriginal man. Between 2000 and 2010, the rate of imprisonment for Aboriginal men increased by $52 \%$ (Australian Government, Australian Institute of Health and Welfare, 2011).

The Commission found that Indigenous people are sentenced to imprisonment for less serious offences, such as traffic infringements, property offences, good order offences, breaches of orders or fine defaults, so one of the recommendations to counter the over-representation of Indigenous men in prison was to use imprisonment as a last resort. The opposite however has been the case, Krieg (2006) commenting that it is questionable whether the recommendations have ever been followed in practice, and Behrendt and Cunneen (1994) saying that often they are breached or ignored all together. An increase in imprisonment as a punishment for minor crimes such as offensive behaviour and offensive language (Cunneen, 1992; 2006) and changes in legislation that have increased the penalty for certain crimes, mean the average length of time served by prisoners has gone up (Cunneen, 1992; 2006). Schwartz (2010) argues that imprisonment has little impact on crime reduction overall, and in Indigenous populations can have the opposite effect. She maintains that the funds required for imprisonment could be better spent on programmes that address the underlying causes of crime.

Although small, and not claiming to be representative, this study was intended as an acknowledgement of this serious Australian Public Health issue that needs to be addressed more fully and give voice to the real people behind the statistics. With this in mind, a programme was set up which enabled a group of men to set part of the agenda to appreciate the strength from telling their story in a supportive environment. The listening to the story of the genesis of their incarceration and the subsequent experience of re-entry into society led to the discovery of some possible and alternative pathways for these men. These initiatives were little steps and are primitive attempts to make a difference in and around the communities from which the men had come.

The Men's Health Information and Resource Centre (MHIRC) has as its primary function the promotion of health for men and boys in a variety of contexts: the workplace, family relationships, and access to health and social support services. As part of its mission, it has focussed on those men most in need, including Indigenous males, through the support of capacity building initiatives from the Aboriginal Health and Medical Research Council, and the ongoing work of The Shed at Mt Druitt, the funding for which comes from the Department of Health (Commonwealth), as part of their Suicide Prevention Strategy. The Shed was established in response to the high rate of male suicide in the Western Sydney area and is a drop-in centre for men at risk. It was a joint venture of the Commonwealth, Western Sydney University (WSU), and Holy Family Centre in Mt Druitt, and has been operating since 2004. It provides a contact point for agencies such as Probation and Parole trying to contact men at the margins, and for men in need of services.

The Shed and the network of agencies attached to it led to the concept of the project initially called: 'Revolving door: Engaging with Indigenous men in the Context of Incarceration', later re-named 'Jumna Wal' ('We Care'). Consultation with the local Indigenous Elders, the Dean of Indigenous Education at WSU, NSW Corrective Services, and Hawkesbury District Health Services Ltd led to the application for a WSU Regional and Community Engagement Grant, which provided the funding for the project. The aim was to establish a small programme which would offer a group of Indigenous men who had been in prison a place where they could tell their stories of their experiences of incarceration. Through this process and with an ongoing support programme it was hoped that they could be helped to regain their dignity and self-respect, and develop skills that would help them re-enter their communities. The cottage on the Hawkesbury Campus of WSU became the venue for remembering deaths in custody, for creating and storing artworks, and a place where the men could then tell their stories. It was a collaborative programme whereby consultation with the local Elders was an integral part of the process. It has been documented that in order to implement change in such an area, a process of decolonisation needs to take place, whereby Indigenous people are involved in the sentencing process, ensuring that they have a voice (Douglas and Corrin, 2010). The interviews were conducted by an Indigenous male, and were aimed at exploring the physical, psychological, financial, 
and social effects that imprisonment had on the men themselves and their families.

MHIRC operates within the framework of Primary Health Care, which incorporates the social determinants of health (Wilkinson and Marmot, 2006), and focusses on non-clinical aspects of health and well-being (Macdonald, 2012). Krieg (2006) says that changes in Indigenous imprisonment rates and recidivism will only occur when social issues such as housing, employment, drug abuse, and mental health problems such as depression and violence are dealt with. Jones and Day (2011) also make the point that so many of the difficulties experienced by Indigenous people derive from underlying cultural concerns, such as dispossession, marginalisation, and inequality, that when the provision of services is required, the responsibility for this gets diffused, and is often overlooked altogether. According to Sahari, 'Violence committed against Aboriginal communities leads directly to violence within communities' (2006). The negative effects of trauma and loss and racism have a powerful impact on health, particularly mental health, and a child health study in Western Australia showed that 22\% of Indigenous children have already had at least seven significant life events in the previous year, which amounts to something happening every few weeks. For the children of Indigenous people who had been forcibly removed from their parents this figure was even higher (Jones and Day, 2011). Although literature is scarce on the subject, it is significant to note that when Indigenous people are given opportunities for self-determination, it has a profound effect on mental illness, with one of the most telling measures being a reduction in the suicide rate of young Indigenous youth, as illustrated in a Canadian study by Chandler and Proulx (2006). To date, Indigenous input into those matters that most affect them has been very low, despite such studies and the growing awareness that Indigenous incarceration and recidivism have their origins in social exclusion, and this, as Carrington (2011) argues, has reached 'an important symbolic significance as a nagging register of unresolved historical injustice' (from Behrendt, 2003).

\section{Methods}

As stated, there were eight participants interviewed, either in a focus group or one on one with an Indigenous interviewer employed by the University. The focus group included an Elder from the local area, the parish priest from the Holy Family Centre, and the main researcher. It has to be noted here that the interview process was limited. Indigenous men find it difficult to discuss certain issues, and as the interviewer was also Indigenous he was aware of this sensitivity, and therefore did not pursue certain avenues of questioning. This meant that answers were brief and not always to the point.

Table 1 gives a brief overview of the participants. The interview questions were as follows:

(1) What age were you when you first went to prison?

(2) How often were you moved around?

(3) What were the supports inside?

Example: family connections, professional or pastoral

(4) What were the supports outside?

Example: family, children or parents

(5) Did you have any money for buy ups ( $N B$ : This refers to extra food and cigarettes available to buy in prison)?

(6) What was your experience with sex and drugs while in prison?

(7) Was there a discharge plan?

(8) What support did you have on your release? Re: mob (Best translated as family, kin, or group of people) or relationship

(9) What was your health like before being locked up and what is it like now?

(10) What services were available to you?

(11) Did you have work or housing opportunities given to you?

(12) What change would you make in your life to make it better?

All participants were Indigenous Australians and so adherence was made to the Australian Government's document 'Values and ethics - guidelines for ethical conduct in Aboriginal and Torres Strait Islander health research' (Australian Government, National Health and Medical Research Council, 2003). In particular, attention was paid to the values outlined in this document: reciprocity, respect, equality, responsibility, survival, protection, spirit, and integrity. Anonymity was assured, and consent was obtained from participants to use the material in the interviews. One other point was raised, and this 
Table 1 Brief overview of participants

\begin{tabular}{|c|c|c|c|c|c|c|}
\hline & $\begin{array}{l}\text { Age at } \\
\text { first } \\
\text { arrest }\end{array}$ & $\begin{array}{l}\text { Duration and number } \\
\text { of stays }\end{array}$ & Reason for incarceration & Support & Health & $\begin{array}{l}\text { Violence/sexual } \\
\text { issues in prison }\end{array}$ \\
\hline Participant 1 & 14 & $\begin{array}{l}\text { Vague about early } \\
\text { years, but only one } \\
\text { stay in prison }\end{array}$ & Could not remember & $\begin{array}{l}\text { Visits from family } \\
\text { only. No support } \\
\text { on leaving }\end{array}$ & $\begin{array}{l}\text { Avoids alcohol so has kept } \\
\text { well }\end{array}$ & $\begin{array}{l}\text { Used violence to } \\
\text { achieve some } \\
\text { immunity from } \\
\text { violence }\end{array}$ \\
\hline Participant 2 & 13 & $\begin{array}{l}\text { In and out for } \\
16 \text { years }\end{array}$ & Not stated & $\begin{array}{l}\text { No support inside, } \\
\text { partner only. No } \\
\text { support on } \\
\text { leaving }\end{array}$ & Hepatitis C & $\begin{array}{l}\text { Victim of violence } \\
\text { from officers and } \\
\text { towards them }\end{array}$ \\
\hline Participant 3 & 19 & Does not remember & $\begin{array}{l}\text { Mixed with the wrong } \\
\text { people and got into } \\
\text { trouble }\end{array}$ & $\begin{array}{l}\text { From partner and } \\
\text { family. No plan } \\
\text { on leaving }\end{array}$ & $\begin{array}{l}\text { Dental issues when in } \\
\text { prison }\end{array}$ & $\begin{array}{l}\text { Declined to } \\
\text { comment }\end{array}$ \\
\hline Participant 4 & 18 & 4 times & Related to drug use & $\begin{array}{l}\text { Visits from family. } \\
\text { No plan on } \\
\text { leaving }\end{array}$ & $\begin{array}{l}\text { Drugs and mental issues - } \\
\text { mainly anger and } \\
\text { depression }\end{array}$ & $\begin{array}{l}\text { Violence related to } \\
\text { drugs }\end{array}$ \\
\hline Participant 5 & 17 & $\begin{array}{l}2.5 \text { years first, then } \\
\text { 'several times' } \\
\text { afterwards }\end{array}$ & Not stated & $\begin{array}{l}\text { Family support. } \\
\text { No support on } \\
\text { leaving }\end{array}$ & $\begin{array}{l}\text { Alcoholism and drugs. } \\
\text { Issue he refused to discuss } \\
\text { - causes him to consider } \\
\text { suicide }\end{array}$ & $\begin{array}{l}\text { Declined to } \\
\text { comment }\end{array}$ \\
\hline Participant 6 & Juvenile & $\begin{array}{l}\text { In and out from } \\
12 \text { years }\end{array}$ & Breaking and entering & $\begin{array}{l}\text { Occasional visits } \\
\text { from family }\end{array}$ & Hepatitis $\mathrm{C}$ and asthma & $\begin{array}{l}\text { Declined to } \\
\text { comment }\end{array}$ \\
\hline Participant 7 & Juvenile & & Traffic fines and vagrancy & $\begin{array}{l}\text { No support from } \\
\text { anyone }\end{array}$ & Mental issues & $\begin{array}{l}\text { Used violence to } \\
\text { avoid being } \\
\text { preyed on for sex }\end{array}$ \\
\hline Participant 8 & 14 & & Used stolen car to get home & $\begin{array}{l}\text { No support } \\
\text { or visits }\end{array}$ & Alcoholism/depression & $\begin{array}{l}\text { No comments } \\
\text { made }\end{array}$ \\
\hline
\end{tabular}


was that participants were not to refer to any criminal activity for which they had not received sentencing, or any proposed criminal activity, as the University would be obliged to notify relevant authorities.

Interviews were analysed for themes related to the questions, and these were mainly first encounter with the judicial system, duration and number of stays, support, health, and violence.

\section{Analysis of interviews}

\section{First encounter with the judicial system}

When asked when they were first imprisoned, five out of the eight participants mentioned that before prison they were in trouble with the authorities and sent to 'boy's homes' at the ages of 13 and 14 years, the others imprisoned at the ages of 17,18 , and 19, respectively. The reasons were often trivial, two mentioning vagrancy (one receiving a three-month sentence for that)

I was in court at Fairfield and there was just a couple of coppers and the magistrate, no-one else, and yeah vagrancy, yeah bang, gone. You know so I did three months, now I lost me job.

(Participant 7)

For another, it was traffic offences and breaches of orders. For a couple of the men who were put into boy's homes, it was a positive experience in many ways, and they mention that they felt 'looked after', had regular meals and a bed, although one constantly ran away from homes. There was a real sense among the men that going to prison had become what life was about for Aboriginal people, and that for many it was not a question of if it might happen, but rather a question of time before it would happen.

\section{Duration and number of stays in prison}

All but one of the participants were recidivist offenders, the one exception saying that, 'once was enough' for him, and he was determined not to go back as it was 'not a good place to be'. Most of the men were vague about the number of times they had been in prison. Many of these men had fathers and relatives that were in prison too, one mentioning that his first stay was made easier because his dad looked after him. The duration of their sentences varied from a few months to three years, and often it was only a matter of weeks before they were back inside. As one participant stated

I'd be in there for a couple of years or something and come out, I'd be out for about two or three months - there's no support there, there's no help outside for you anywhere - and before you know it you end up in the same situation, you end up back in gaol again for something you've done, something pretty minor but the judge's got to make an example of you every time.

(Participant 8)

A number of participants gave boredom as a reason for their repeat offending; alcohol figured strongly and was sometimes linked to the first; not having the means to support themselves was significant, too; and violence for some was a factor, which was often related to alcohol.

Most of the participants mentioned that their motivation for participating in the interviews was a deep concern for their young men and the hope that in telling their stories they could be instrumental in making change happen for younger Indigenous people.

\section{Support inside and outside prison}

When asked about support, every one of the participants said that they felt very unsupported. When first confronted with the system they were given very little help or representation. They described growing up without much support from families because often their parents were separated, or father was in prison. They each felt that for many of the single women trying to bring up a number of children, the task was too difficult, because they, too, had little support. This is an often-repeated pattern, then, with their own children once they were themselves in prison, one man voicing that his greatest regret was that he had let his children down, by not being there for the death of a family member. For those who had been in boy's homes, they talked about helping out on farms, and being able to participate in different activities, but once they left, there was no follow-up. Invariably, this led to further encounters with the law.

Once in prison, all participants said that there was no support within the system, although before 
entering they were told that there would be. Whilst there were some courses available, the process of applying took a long time, and since some of their sentences were short, it was not viable. A Number of men said that seeking help was seen as a sign of weakness, and would leave them vulnerable. One man said that he had been harassed by the prison officers when he had tried to seek help from the Ombudsman, and his repeated requests to see the chaplain were ignored. There were some jobs available, but the pay was low, and the men usually relied heavily on receiving some money from their families in order to buy cigarettes and extra food. For most of the men their families were the main support, especially a wife or a partner, and this factor was significant when they left prison. Four of the men mentioned that it was only when they had a home to go to that they were able to break the pattern of repeat offending. Without this they were on the street, and it was a question of 'fighting for myself' as one man put it, and another, '...you just sign and go'. One described deliberately breaking the law, so that he would be re-arrested and then be sure of regular meals and a bed, '...back to crime is where you go'. Visits from family were important, and alleviated much of the stress the men felt at being locked up

With the visits, they, sort of, like levelled out the emotion, they calmed me down; took away a lot of the stress. I've just been with men all the time.

(Participant 1)

However, it depended on where they were, a number of men mentioning being moved around in the prison system and therefore being placed out of reach of visits from family at times.

Then I spent three months in Goulburn, spent three months down at Mannus and then the woman -my wife couldn't come and visit me and she complained about it so I asked to be transferred back to Goulburn and I spent the last three months there.

(Participant 1)

This was often a source of great stress for the men and their families.

The intervention of the Shed at Mt Druitt figured strongly in the men's stories. It was a place to go on leaving prison, and a place to connect with various essential support services. Without this, as one participant put it, there was nothing

No, no discharge plan whatsoever. I just had to - when I got discharged, it was fight for myself once I got out sort of thing. They don't give you anything like that.

(Participant 4)

At the Shed, they were given help to find employment, and more than anything, the men described that being there relieved the boredom of their lives, they had something to do, to work towards. As one man says

I want to be there because it's fun, it's good work. Keeps me out of trouble. It keeps my head occupied.

(Participant 2)

Boredom is a common theme in the stories of the men, many saying that it was often why they got into trouble. One man expressed that this is still the main problem with their young men today

'You know, there's got to be something, them kids are all walking around bored and all they've got to turn to is alcohol and drugs'.

(Participant 8)

They expressed a desire to have employment, but deplored the lack of skills required for this, and the lack of opportunity to acquire those skills, some commenting that their time in prison could have been productive if they could have received training in basic skills. Even something as simple as attaining a driving licence is out of the reach of some of these men, and could have been addressed whilst in prison. As one man said it could have alleviated the boredom and helped towards getting a job. Help with handling finances is a theme that arose; the men felt that it would have been helpful to learn these skills whilst in prison.

\section{Health issues - drugs/alcohol - depression}

Most of the men (six out of eight) had a problem with alcohol, or alcohol and drugs. It was seen as the main cause of their imprisonment, often because it led to violence. The reasons given for resorting to drugs and alcohol were boredom (as already mentioned), depression, and stress. One man related that he had a traumatic incident in prison, on which he did not want to elaborate in 
the interview, but which has made him consider suicide. He still suffers from this, but has never received counselling even though it is a major reason for resorting to drugs (the interviewer did offer to find appropriate counselling at this stage, but the participant is so traumatised he is still not able to talk about it, but said he would give it some serious thought). Another mentioned losing two family members close to him in a short space of time. He was deeply affected by this, but has never been counselled. Even though violence (often domestic violence) figures strongly in the narratives, none have received anger management treatment. One man was able to break his cycle of recidivism by realising that it was always related to alcohol, so for many years he has abstained from drink, now partaking occasionally with his son. He has avoided the prison system for 16 years.

For these men the stress of their lives, trying to find employment and housing, struggling with alcoholism, drug addiction, problems related to the management of finances, was extreme. As, too, was the sense of always being discriminated against

We've been nobodies all our life, people have been looking down on us from all over the world. They come here from different countries and look down on us. I've been even told to get back to me own country, by new Australians, but yeah there's a lot of negatives there that need to be fixed up.

(Participant 8)

This situation then worsened once they became prisoners, or ex-prisoners. One man said 'You are no longer human when you're an offender' (Participant 7); another saying you have 'no rights'. Some of the men voiced always being 'looked down on' in society by white people generally and by the police in particular. A few mentioned that sentences for Aboriginal men were longer than white Australians for the same offence

A lot of them are doing times for crimes that other people are only given half the time for. No, I say that all the time you know. You get someone there doing ten years whereas if for the bloke in the next cell for the same crime is doing three or four.

(Participant 8)
One man described police violence towards his family in their home. He and another described violence towards them whilst in custody.

In terms of general health one participant maintained that having regular good meals in prison improved his health, but he was afraid of contracting AIDS because of shared needles in prison. Others said their health deteriorated whilst in prison, and improved when they left, one man suggesting that they were not fed much as the prison officers were concerned they would be harder to handle if they got too big. One man had dental problems for which he failed to get treatment whilst in prison, and which affected his health adversely, a situation he was able to improve on once he left. A couple of participants mentioned having Hepatitis $\mathrm{C}$, one of them contracting this whilst in prison

\section{Experience with sex and drugs and violence in prison}

All the participants were aware that drugs were readily available in prison if you had the money to buy. As already mentioned, some of them were afraid of contracting AIDS because of the shared needles. One described coming back to his cell to find a group of men sharing a needle to inject drugs. At the time of the interview some of the men said they had not used drugs for a number of years, and this did seem linked to being supported either by a partner or by the Shed.

Most of the men refused to talk about sexual issues, although some said they were afraid of rape when first entering prison, and took care to keep away from transvestites and gay men. Two men described using violence very early in their prison term, and this gave them a degree of protection

One hit each, whack, whack and they were out for the count. People seen it and then I had protection, I didn't have to do nothing after that.

(Participant 1)

...you know it got a little bit rough so I just cracked everyone over the head that made it rough for me and sat in the corner and minded my own business.

(Participant 7)

One describes being on remand for bashing a prison officer, and then being bashed by prison officers. 


\section{Discussion}

Using the Foucault concept of biopower, and applying it to an Australian context Carrington (2011) maintains that the criminalisation of Indigenous people has its roots in Australia's convict history and the perceived need to 'protect' white British stock from racial contamination. She describes how the use of 'deficit discourses' which depict Aboriginal people as 'a dangerous presence', 'the unruly, unchaste, unlawful and primitive' (Carrington, 2011: 33) was a way of justifying their incarceration into missions and reserves. This made it easier for governments to police and supervise those who were not considered part of the mainstream population (a process, incidentally, that can still be seen in the criminalisation of certain groups of people such as 'illegal' immigrants. They are labelled 'queue jumpers', 'boat people', 'aliens', 'clandestines', etc. thus ensuring their separation from mainstream populations) (Carrington, 2011). The men that were interviewed in this study could describe walking with a white male and being stopped by police, the white person able to carry on, the Aboriginal man taken into custody. One Participant (8) said '...we're scruffy, the judge has to make an example of us'. The general principle in sentencing is to use imprisonment as a last resort (Douglas and Corrin, 2010), and this was certainly the advice of the RCADC (1991). The reality, however, is that rates of imprisonment for Aboriginal people continues to increase, figures showing that between 2004 and 2014 an $88 \%$ increase for Indigenous men occurred, compared with $28 \%$ in the non-Indigenous population (Law Council of Australia, 2015).

An article by Zipin et al. (2013) has some resonance here. They maintain that recent Australian government policy that aims at encouraging the 'raising of aspirations' of those from low socioeconomic backgrounds so that they can improve their conditions, ignores the most complex obstacles that confront certain groups of people. Those who then 'fail' are constructed in those deficit discourses as having 'wasted lives', or being 'drains on society'. However, as the authors point out, in order to have failed you must first have had the opportunity to succeed, and this is not the case with so many who are born into poverty or who belong to certain ethnic groups that have a long history of exclusion. To talk optimistically therefore of 'raising aspirations' can be cruel, and result in the exact opposite (Zipin et al., 2013).

The Commission (RCADC, 1991) was categorical that it was disadvantage and a long history of social exclusion that produced the high rates of Aboriginal people in the criminal justice system, and until the persistent criminalisation of these people ceases there will be little change in the figures (Cunneen, 2006). As stated earlier, strategies to decolonise justice need to be implemented, so that Aboriginal people have a real voice in the process of sentencing (Douglas and Corrin, 2010). It is clear from these men's stories that the negative effects of imprisonment go beyond the sentence itself, and Quilty (2005) stresses the need to use alternative options such as rehabilitation and working with the families, particularly during incarceration and following release. Krieg (2006) also maintains that problems surrounding recidivist offenders derive from the basic needs of housing and transport being unmet at the point of leaving prison. Centrelink (Government Department of Human Services) offers financial support to ex-prisoners for one or two weeks after release, but after that, they have to resort to family members, which often places an impossible burden on them. All men in this study articulated the difficulty of leaving prison without any available support. There is a scarcity of literature on post incarceration, the first six to 12 months being very high risk, re-offending or suicide being the solution for some men. In terms of health, if there is no access to housing or income, then appointments for health or counselling are impossible to keep, and many treatments, which may have begun in prison are abandoned (Krieg, 2006). This is why the intervention of the Shed factored so positively in the men's stories. It is a place to go when there is no where else to go, it is a place to meet with others and with those essential services that can intervene and lead to more positive outcomes.

Mainstream Australian health services are inadequate to deal with the complex problems of Aboriginal families, which, as Aboriginal people have been saying for a long time, are a consequence of the build up of anger and pain experienced on a daily basis. Rather than pathologise the plight of Aboriginal men; however, it is important to recognise the power in their stories as a call for early and generational intervention that is commensurate 
with their culture, family, health, education, employment, and all the social determinants. It is only when serious social matters are addressed that any gains will be achieved, and the cycle of recidivism broken. This calls for an innovative and an exploratory approach to post release Aboriginal men, driven and owned by the participants themselves with appropriate supports and skills.

Jumna Wal was a very small testimony to a community-based programme that attempted to give ownership and direction to a group of Aboriginal men who could see themselves setting a new agenda for significant re-entry into society and renewing their self-esteem and all that follows for their family and community at large, and affecting social policy without knowing it. Finally, Jumna Wal's short journey pointed to a pathway that would need to have a transgenerational approach from a community base and enable the major stakeholders like Corrective Service, Probation and Parole, Juvenile Justice, The Court Systems, Policing, The University, other supervising authorities conjointly network for the common good of all concerned and for change in the social policy of the current prison, judicial, policing, and allied authorities.

One cannot claim that the Shed in Mt Druitt, Western Sydney, offers the model to work alongside Indigenous men coming out of prison, but at least it points the way towards a solution. Although inevitably this work is concerned with a specific group of men in a particular geo-political context, it is perhaps true to say that the approach taken, both to listening to the men and to walking alongside them after their release may have implications for other countries. A safe place for men, a place where they can come into respectful contact with services which are set up to help them, be they legal, housing, or family relationship services must surely be a step in the right direction, albeit a very small one.

\section{Acknowledgements}

The authors acknowledge those men who participated in this work by sharing their often difficult experiences of incarceration and whose anonymity is respected. In keeping with the spirit of Aboriginal culture, we also acknowledge the traditional elders and custodians of the land on which the interviews were conducted, namely

Primary Health Care Research \& Development 2016; 17: 568-577 the Darug, Tharawal, Gandangarra and Wiradjuri peoples.

\section{References}

Australian Government, Australian Institute of Health and Welfare. 2011: The health and welfare of Australia's Aboriginal and Torres Strait Islander people: an overview. Retrieved May 2015 from http://www.aihw.gov.au/WorkArea/DownloadAsset.aspx?id=10737418955.

Australian Government, National Health and Medical Research Council. 2003: Values and ethics - guidelines for ethical conduct in Aboriginal and Torres Strait Islander health research. Retrieved April 2016 from http://www. nhmrc.gov.au.

Behrendt, L. 2003: Achieving social justice: Indigenous rights and Australia's future. Annandale, NSW: Federation Press.

Behrendt, J. and Cunneen, C. 1994: A report to the National Committee to defend black rights: Aboriginal and Torres Strait Islander custodial deaths between May 1989 and January 1994. Aboriginal Justice Issues II, Conference paper presented by Chris Cunneen. Retrieved October 2014 from http://www. aic.gov.au/media_library/conferences/1994-aboriginal/cunneen. pdf.

Carrington, K. (2011): Punitiveness and the criminalisation of the other: State wards, Unlawful, non-citizens and indigenous youth. Edinburgh University Press. Somatechnics 1, 30-47.

Chandler, M. and Proulx, T. 2006: Changing selves in changing worlds: youth suicide on the fault-lines of colliding cultures. Archives of Suicide Research 10, 125-40.

Cunneen, C. 1992: Aboriginal imprisonment during and since the Royal Commission into Aboriginal Deaths in Custody. Current Issues in Criminal Justice 3, 351-55.

Cunneen, C. 2006: Aboriginal deaths in custody: a continuing systematic abuse. Social Justice 4, 37-51.

Cunneen, C. 2007: Reflections in criminal justice policy since the Royal Commission into Aboriginal Deaths in Custody. In N. Gillespie, editor Reflections: 40 years on from the 1967 referendum, Aboriginal legal rights movement. UNSW Law Research Paper No. 2008-7. Adelaide, 135-46. Available at SSRN: http://ssrn.com/ abstract $=1392054$

Douglas, H. and Corrin, J. 2010: 'A tragedy of monumental proportions': Indigenous Australian and the sentencing process. Social and Legal Studies 194, 197-215.

Jones, R. and Day, A. 2011: Mental health, criminal justice and culture: some ways forward? Australasian Psychiatry 4, 325-30.

Krieg, A.S. 2006: Aboriginal incarceration: health and social impacts. Medical Journal of Australia. 10, 532-36.

Law Council of Australia. 2015: Change the record on Indigenous imprisonment. Media Release. Retrieved December 2015 from https://www.lawcouncil.asn.au/lawcouncil/ images/1518_-_Change_the_record_on_indigenous_impri sonment2.pdf. 
Macdonald, J. 2012. Primary health care: medicine in its place. London: Earthscan.

Royal Commission into Aboriginal Deaths in Custody (RCADC). 1991: Report available fom http://www.austlii. edu.au/au/other/IndigLRes/rciadic/.

Sahari, S. 2006: Listen to male voices. Australian Doctor, 25.

Schwartz, M. 2010: Building communities, not prisons: justice reinvestment and Indigenous over-imprisonment. Australian Indigenous Law Reporter 1, 2-17.
Quilty, S. 2005: The magnitude of experience of parental incarceration in Australia. Psychiatry, Psychology and Law 12, 256-57.

Wilkinson, R.G. and Marmot, M. 2006: editors Social determinants of health. Oxford: Oxford University Press.

Zipin, L., Sellar, S., Brennan, M. and Gale, T. 2013: Educating for futures in marginalized regions: a sociological framework for rethinking and researching aspirations. Educational Philosophy and Theory 47, 227-46. 